\title{
OBITUARY NOTICE OF DECEASED MEMBER
}

\section{Thelen Altken Wraright}

\author{
13 April 1895-27 August 1972
}

Helen AitKen Wright died unexpectedly in her own home in Edinburgh on 27 August 1972, at the age of 77, while still seemingly in the full vigour of a very active life.

She was born in Leith and educated in Edinburgh at St George's School for Girls. The eldest of a family of seven children, she lost her mother before she had finished her last years at school. There then followed several years during which she had the responsibility of running the household and caring for her family. All the time she had to hold in check her ambition to become a doctor and it was not until April 1921, when she was 26, that she was finally free and could enter the Medical School of the University of Edinburgh.

She passed her First Professional Examination "with distinction" and graduated M.B., Ch.B. on 23 July 1926. At the time of her training, the Medical School provided separate classes for the women, who also had their own student's union. In her undergraduate years, Helen Wright was very active in the affairs of the Women's Union and served first as its Secretary and then as President. This was a time when women entering the medical profession felt strongly that they were pioneers and that the path they trod would open the way for their successors to find full recognition and fulfilment.

Helen's first postgraduate assignment was to work as an assistant for 18 months in the medical wards of the Royal Infirmary of Edinburgh. A natural interest in infectious diseases was later to lead her into the departments of dermatology, venereology and diseases of the ear, nose and throat.

In 1927 she went abroad to take a post as medical officer to the Jeanes School, at Kabete in Kenya, where she spent two and a half years in general medical duties, but concentrating on child welfare and maternity work. Although she greatly enjoyed all the aspects of her medical work and developed a flair for teaching the methods of hygiene and mothercraft to the local people, she found it difficult to tolerate the tropical heat. When her tour of duty was over she returned gratefully to Scotland and was never tempted again to work abroad.

On her return she entered the course for the D.P.H. in Edinburgh and she combined this with a part-time post as House Officer at the Astley Ainslie Hospital. Her aptitude for the study of infectious diseases was encouraged and developed by the dynamic enthusiasm of Professor T. J. Mackie in the University Bacteriology Department, and in 1930 she began part-time work in the Department on the use of antiformin and on selective methods of cultivation of the enteric bacteria and Corynebacterium diphtheriae.

In 1932 she was appointed as Bacteriologist and Assistant Pathologist to

J. MED. MICROBIOL.-VOL. 6 (1973) 
the Royal Hospital for Sick Children in Edinburgh, a post she held for the next 11 years. She and her colleague Dr Agnes Macgregor, who was in charge of the pathology laboratories, added much to the reputation of the investigative work of the hospital. Together they became well-known figures in the academic life of the Edinburgh School of Medicine; both took prominent and important parts in teaching and each won the friendship and respect of the students. To many they were known by their christian names and Helen Wright was ever after known affectionately as "Nell".

Meantime she was carrying out an investigation on cases of chronic Escherichia coli cystitis in an attempt to assess the comparative values of potassium citrate, hexamine and neotropin as therapeutic agents. She reached no definite conclusions, but was one of the first to realise that the accurate counting of the numbers of bacteria in the urine was of paramount importance in assessing the value of a therapeutic drug. As the holder for three years of a Crichton Stewart scholarship, she worked in the University Bacteriology Department as well as in the Children's Hospital.

Away from work, Nell had no easy time to organise her private life. In addition to looking after her own house, she had innumerable friends, as well as her family, with whom she regularly maintained contact and whom she felt duty bound to visit socially or, if they took ill, to see regularly in hospital and at home. She loved music and was an ardent concert-goer and a regular attender at the evening classes in Gaelic and in horticulture. During the University vacation she and her companions were to be found in the central highlands camping at Lochearnhead with the Edinburgh Club for Schoolgirls or exploring the Orkneys, the Shetlands or the outer islands.

At the beginning of the Second World War, Nell was seconded to establish a regional bacteriological laboratory of the Emergency Medical Services at Ayr. In the following year she was recalled to the east of Scotland to set up a bacteriological service for the newly organised E.M.S. Bangour Hospital in West Lothian. Her abilities in bacteriological and epidemiological work were by now abundantly clear and her services were invaluable under wartime conditions.

With so many of the staff of the medical school on active service, it was not surprising that Professor Mackie invited her to return to his department, and in 1943 she accepted the offer of a full-time lectureship. She had charge of a great part of the bacteriological work provided by the University for the Public Health Department of the City of Edinburgh and for south-east Scotland, and played an important role in teaching both undergraduate and postgraduate students.

Her constant insistence on attention to detail and her intolerance of inaccuracies and short-cuts made her a hard task-master, but her warm and kindly personality made sure that the work was willingly done and finished in good time. She made it her business to know her staff very well, and the welfare of them all was of the greatest concern to her. All her professional colleagues in the laboratory enjoyed her wisdom and experience and, as well as their families, became her personal friends. 
At first her main interest was the diphtheria bacillus, and she became an acknowledged authority on the biotypes of this organism and their distribution and clinical significance in the community. But her interests in clinical bacteriology were catholic; her activities included an investigation of the aerobic actinomycetes and ranged over the whole field of infective disease, and she was continually in consultation with all who were concerned in controlling the spread of infection in south-east Scotland.

After the war she was put in full charge of the area bacteriological services provided by the University Department, and in 1950 was promoted Senior Lecturer and accepted the post of Honorary Consultant Bacteriologist to the South-Eastern (Scotland) Regional Hospital Board of the new National Health Service.

In this same year, she contributed a survey of the 50 preceding years of the Bacteriological Services provided for the Public Health Department of the City and Royal Burgh of Edinburgh. Events during the first half of the twentieth century were well within her experience, and she had witnessed the effects of a clean water supply and improving sanitation and housing. She herself played a big part in safeguarding Edinburgh's supply of milk. She saw the eradication of bovine tuberculosis, the disappearance of diphtheria and typhoid fever and the gradual decline of human tuberculosis and syphilis. From 1932 onwards she saw to it that the milk and water supplied to the City of Edinburgh were examined regularly for bacteriological purity and, under her aegis, a constant watch was maintained on the bacteriological cleanliness of the foodstuffs supplied from the abattoir, bakeries, shops and restaurants.

She had a particularly close relationship with the Medical Officers of Health of the three Lothian counties and with the inspectors on their staffs. Because of her concern in tracing the paths of the spread of infection, she was always interested in the work that led her colleagues in the field to the discovery of the original source and its elimination.

To her colleagues in the laboratory she was first and foremost an outstandingly good clinical bacteriologist. Her professional conscience was highly sensitive, so that not a single error escaped her eagle eye. Younger colleagues found her sternly critical in training and learned from her how very important it was to be sure of the accuracy of any laboratory findings before any written report was allowed to leave the laboratory. Much of her time was willingly spent in personal contacts and in telephone conversations with colleagues. As the work of her laboratory grew, so did her own reputation, and her wise advice was continually sought by the profession far and wide in southeast Scotland. Her laboratory became a focal point for the dissemination of epidemiological data no matter when it had been obtained. Gradually these activities crowded her research interests out, and she was obliged to reduce her teaching activities. Nevertheless she would always find time to lecture to the DPH class on her own special areas of interest.

When she retired from the Department in 1960, she was rather unwillingly persuaded to return to her old, beloved Astley Ainslie Hospital and take charge of the bacteriological laboratory. This work she undertook as a friendly 
obligation, but she was strong-minded enough to insist on giving it up about a year later.

At last Nell was free to follow her many personal interests. She could enjoy her own house and began to set to rights her delightful garden. She had always many special interests in its charming wild design and enjoyed growing many unusual and striking plants. Naturally, she continuously despaired of bringing it to the pitch of perfection that she had insisted on in her own laboratory. She had time to enjoy the company of her own family, took great pleasure in the activities of her nieces and nephews and their families and visited her friends all over Scotland. In this busy life she was often accompanied by her dear friend Kay Wernincke and, together with a friendly dog, they divided their time between their houses in Edinburgh and in Walkerburn in the Borders. Nell's last years were happy ones and she spent them in the full continuation of all her many friendships.

As one who worked with Nell in joint charge of a very large and active University Department, the writer has many memories of her kindness and good humour, and of the twinkle in her eye when she was about to administer a mild rebuke. Outside the laboratory, Nell was particularly good company and always could transfer her abiding enthusiasms for all the many happy and good things of Scotland and its people. She could guide anyone to the glories of the moors, and the hillsides of the country and her great pleasure lay especially in the North and all the Scottish islands. Fresh air and walking over the moorlands in her tweeds and sensible shoes were her special pleasures, and beyond everything she enjoyed the vivid colours of the countryside in all her expeditions. She knew and loved every inch of the countryside and was a peerless ambassador for all that is best in Scotland.

Nell combined all the qualities of supreme professional competence, staunch independence and an absolute intolerance of everything that was slovenly and incompetent. But she had too all the gentle graciousness of the traditional Scottish hostess.

$$
\text { R. H. A. SWAIN }
$$

\section{BIBLIOGRAPHY}

1932

Helen A. Wright and A. W. L. RankIN. Biological types of diphtheria bacillus and their clinical significance. Lancet, 1932, 2, 884-887.

\section{4}

Notes on a series of thirty-seven cases of chronic B. coli cystitis. Edinb. Med. J., 1934, 41, 443-447.

Helen A. Wright and May H. Christison, in collaboration with A. L. K. Rankin, R. C. M. Pearson and J. A. CuthBert. Further observations on the types of Corynebacterium diphtheriae. J. Path. Bact., 1935, 41, 447-467. 
May H. Christison, Helen A. Wright and Barbara J. Shearer. A note on diphtheria carriers with reference to types of $C$. diphtheriae. J. Path. Bact., 1936, 43, 345-350.

may H. Christison, Helen A. Wright, Barbara J. Pearson and R. C. M. Pearson. Corynebacterium diphtheriae in Edinburgh. The incidence of types among cases and carriers from 1932-1936. Edinb. Med. J., 1936, 43, 747-759.

\section{7}

A stable type of variant in certain aerobic Actinomycetes. Zentbl. Bakt. ParasitKde, 1 Abt. Orig., 1937, 138, 201-210.

Helen A. Wright and Agnes R. MacGregor. A case of meningitis due to Bacterium monocytogenes. J. Path. Bact., 1939, 48, 470-472.

\section{0}

A survey of the biological types of the diphtheria bacillus in Edinburgh, 1932-1939. Edinb. Med. J., 1940, 47, 541-552.

\section{3}

The laboratory diagnosis of diphtheria. A note on some present-day methods. Edinb. Med. $J ., 1943,50,737-745$.

1950

Bacteriological services in Edinburgh. The first 50 years. Annual Report of the Public Health Department of the City of Edinburgh. 1950, 63-66.

\section{5}

J. O. Forfar, A. F. Maccabe, C. L., Balf, Helen A. Wright and J. C. Gould. Staphylococcal infection in the newborn treated with erythromycin. Lancet, 1955, 1, 584-587.

\section{7}

Helen A. Wright, J. Norval and A. ORR. Salm. thompson gastro-enteritis: report of two outbreaks. Brit. Med. J., 1957, 2, 69-71.

\section{0}

R. S. Sloan, H. D. Wirson and Helen A. Wright. The detection of a carrier of multiple phage-types of Salmonella paratyphi B. J. Hyg., Camb., 1960, 58, 193-200. 